\title{
Apoptosis or retinoblastoma: alternative fates of photoreceptors expressing the HPV-16 E7 gene in the presence or absence of $\mathrm{p} 53$
}

\author{
Kimberly A. Howes, ${ }^{1}$ Nancy Ransom, ${ }^{2}$ David S. Papermaster, ${ }^{2}$ Jacques G.H. Lasudry, ${ }^{3}$ \\ Daniel M. Albert, ${ }^{3}$ and Jolene J. Windle ${ }^{1,4,5}$ \\ ${ }^{1}$ Department of Cellular and Structural Biology and ${ }^{2}$ Department of Pathology, The University of Texas Health Science \\ Center at San Antonio, Texas 87284 USA $^{3}{ }^{3}$ Department of Ophthalmology, University of Wisconsin, Madison, Wisconsin \\ 53792 USA $_{;}{ }^{4}$ Cancer Therapy and Research Center, San Antonio, Texas 78229 USA
}

\begin{abstract}
A transgenic mouse model for retinoblastoma was produced previously by directing SV40 T antigen expression to retinal photoreceptor cells using the promoter of the interstitial retinol-binding protein (IRBP) gene. This gene becomes active prior to the terminal differentiation of photoreceptors. Because $T$ antigen-transforming activity is attributable, at least in part, to the inactivation of the retinoblastoma (pRb) and p53 tumor suppressor proteins, we addressed the role of p53 in the development of retinoblastoma in mice. Transgenic mice expressing HPV-16 E7 under the control of the IRBP promoter were generated to inactivate $p R b$ in photoreceptors while leaving p53 intact. Rather than developing retinoblastomas, the retinas of these mice degenerate due to photoreceptor cell death at a time in development when photoreceptors are normally undergoing terminal differentiation. The dying cells exhibit the histological and ultrastructural features of apoptosis and contain fragmented DNA. p53 is required for the induction of apoptosis in this model, because mice expressing $\mathrm{E} 7$ in a 55 nullizygous background develop retinal tumors instead of undergoing retinal degeneration.
\end{abstract}

[Key Words: Retinoblastoma; apoptosis; transgenic mice; photoreceptors; p53; HPV E7]

Received March 25, 1994; revised version accepted May 3, 1994.

The human ocular malignancy, retinoblastoma, has been widely studied as a model for genetic predisposition to cancer. Retinoblastoma arises from cells in which both alleles of the retinoblastoma susceptibility gene $(R B)$ have been mutated (Friend et al. 1986; Fing et al. 1987; Lee et al. 1987; Dunn et al. 1988; Horowitz et al. 1989). $R B$ is therefore designated as a tumor suppressor gene, as loss of function of this gene is tumorigenic /Cavenee et al. 1985). $R B$ inactivation is involved in the development of other carcinomas as well, including bone, soft tissue, lung, prostate, breast, and bladder cancers (Harbour et al. 1988; Lee et al. 1988; Yokota et al. 1988; Varley et al. 1989; Bookstein et al. 1990; Hensel et al. 1990).

The first animal model for heritable retinoblastoma was generated from the retinal-specific expression of simian virus $40 \mathrm{~T}$ antigen (SV40 Tag), a transforming gene that has been reproducibly used to induce tumors in transgenic mice (e.g., Hanahan 1985; Mellon et al. 1990; Windle et al. 1990). This transgenic mouse model resulted from the integration of a luteinizing hormone

\footnotetext{
${ }^{5}$ Corresponding author.
}

$\beta$-subunit-Tag transgene presumably near a retinal-specific gene that targeted Tag expression specifically to cells within the inner nuclear layer of the retina (Windle et al. 1990). Mice of this transgenic line, LT3, heritably develop retinal tumors with features of human retinoblastoma. Additional transgenic mouse models for retinoblastoma have been produced by directing Tag expression specifically to cells of the photoreceptor lineage using the promoter region of the human or murine interstitial retinol-binding protein (IRBP) gene (AlUbaidi et al. 1992; Howes et al. 1994). The IRBP-Tag mice rapidly develop ocular and pineal tumors with histopathological features of human trilateral retinoblastoma.

SV40 Tag (DeCaprio et al. 1988) complexes with and functionally inactivates the retinoblastoma tumor susceptibility protein, $\mathrm{pRb}$, through a domain that is also essential for its transforming activity (Nevins 1992). In addition to pRb, SV40 Tag binds and disrupts the function of another tumor suppressor protein, p53 (Lane and Crawford 1979; Linzer and Levine 1979; Mietz et al. 1992). Although disruption of the p53 gene is the most common genetic lesion identified in human tumors 
(Hollstein et al. 1991; Levine et al. 1991; Oren 1992), p53 mutations have rarely been identified in retinoblastomas (Hamel et al. 1993).

Thus, to clarify the involvement of p53 inactivation in retinoblastoma development in the transgenic mouse system, we produced mice in which the IRBP promoter directs expression of the human papillomavirus type 16 (HPV-16) E7 protein. Like SV40, the HPV-16-transforming activity in several cell types is mediated, at least in part, by the inactivation of both $\mathrm{pRb}$ and $\mathrm{p} 53$, although by two separate proteins. $\mathrm{pRb}$ is functionally inactivated by the E7 protein (Dyson et al. 1989; Munger et al. 1989) while p53 is inactivated by E6 (Scheffner et al. 1990). The IRBP-E7 transgene therefore is expected to result in the inactivation of $\mathrm{pRb}$ in the photoreceptor cells of transgenic mice while leaving p53 activity intact.

In contrast to IRBP-Tag transgenic mice, IRBP-E7 mice do not develop retinal photoreceptor tumors. Instead, during the period of maximal photoreceptor cell differentiation in normal mice, photoreceptor precursors undergo massive apoptosis, resulting eventually in the total loss of the photoreceptor layer. Furthermore, the induction of apoptosis in these mice is mediated by p53, as the expression of IRBP-E7 in mice that are nullizygous for the p53 gene results in the development of retinal tumors rather than apoptosis.

\section{Results}

\section{Generation of IRBP-E7 transgenic mice}

To determine whether $\mathrm{pRb}$ inactivation in the presence of wild-type p53 can induce retinoblastoma in mice, we produced six IRBP-E7 transgenic mice with the transgene shown in Figure 1. The IRBP promoter has been shown to direct expression specifically to photoreceptor cells of the retina and to the pineal gland (Liou et al. 1990; Yokoyama et al. 1992). HPV-16 E7 binds pRb as well as other cell cycle regulatory proteins (Dyson et al. 1992; Arroyo et al. 1993) but does not inactivate p53. Five of the six founder mice exhibited retinal degeneration upon histological analysis. Transgenic mouse lines were established from three of these founders, IRBP-E71, IRBP-E7-4, and IRBP-E7-6, but we were unsuccessful in establishing lines from IRB-P-E7-3 and IRBP-E7-5. Southern analysis of DNA from IRBP-E7-1, IRBP-E7-4, and IRBP-E7-6 revealed that they contained $\sim 10,7$, and 1 copies of the transgene, respectively (data not shown). IRBP-E7 transgenic pups from each line are usually smaller than their nontransgenic littermates for reasons that have not yet been explored. In addition, they often exhibit narrowed ocular fissures from the day that their eyes open (P12) through adulthood. The remaining founder (IRBP-E7-2) and his offspring exhibited normal retinal development, presumably because of failure to express the transgene, and were therefore not studied further.

\section{IRBP-E7 mice undergo retinal degeneration}

All offspring from the three established IRBP-E7 lines heritably develop retinal degeneration because of the specific loss of photoreceptor cells during retinal development. All subsequent analyses were performed with mice from the IRBP-E7-1 line. Figure 2 compares the retina of a 4-week-old IRBP-E7-1 mouse (Fig. 2c) to retinas from a normal 4-week-old mouse (Fig. 2a) and a 2-week-old IRBP-Tag (IT-2) mouse (Fig. 2b). The IRBPE7-1 retina shows neither normal retinal architecture nor the transformed phenotype observed in the IT-2 line. Rather, the photoreceptor cell layer is completely absent and the inner nuclear layer directly abuts the retinal pigmented epithelium (RPE).

A more extensive analysis of the early stages of retinal development in IRBP-E7-1 mice was therefore conducted to better characterize the onset of photoreceptor loss in these mice. IRBP-E7-1 mice ranging in age from embryonic day $16(\mathrm{E} 16)$ to postnatal day $10(\mathrm{P} 10)$ were sacrificed, and eyes were collected for histological analysis (Fig. 3). On E16, no differences between the retinas of control and transgenic mice are observed. Comparable mitotic activity is present in the outermost row of the ventricular cell stratum (Fig. 3a,b). By P1, the overall appearance of the transgenic mouse retina appears similar to the control retina, but subtle changes within the ventricular layer become visible. The outermost cell layer of the ventricular stratum exhibits an increase in the number of dying cells (Fig. 3c,d). By P4, there is an obvious population of dying cells /some of which appear in clusters) within this layer in the transgenic retinas. This developmental stage shows the greatest difference

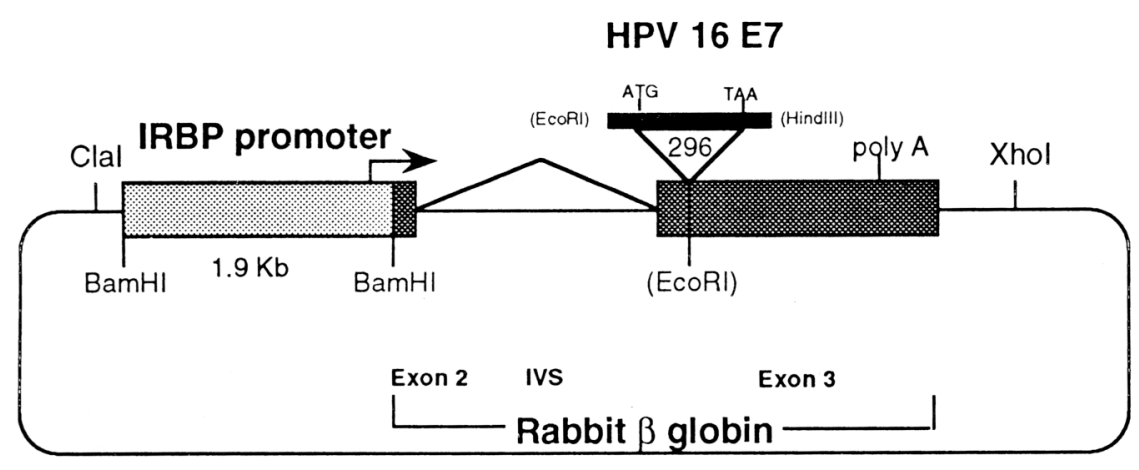

Figure 1. Schematic representation of the IRBP-E7 transgene. Approximately $1.9 \mathrm{~kb}$ of the murine IRBP promoter (including the transcription start site) was inserted $5^{\prime}$ to the HPV-16 E7 open reading frame. Polyadenylation and splicing elements were provided by the rabbit $\beta$-globin sequences contained within the construct. The $3.4-\mathrm{kb}$ ClaI-Xhol fragment containing the IRBPE7 transgene was isolated for microinjection. 


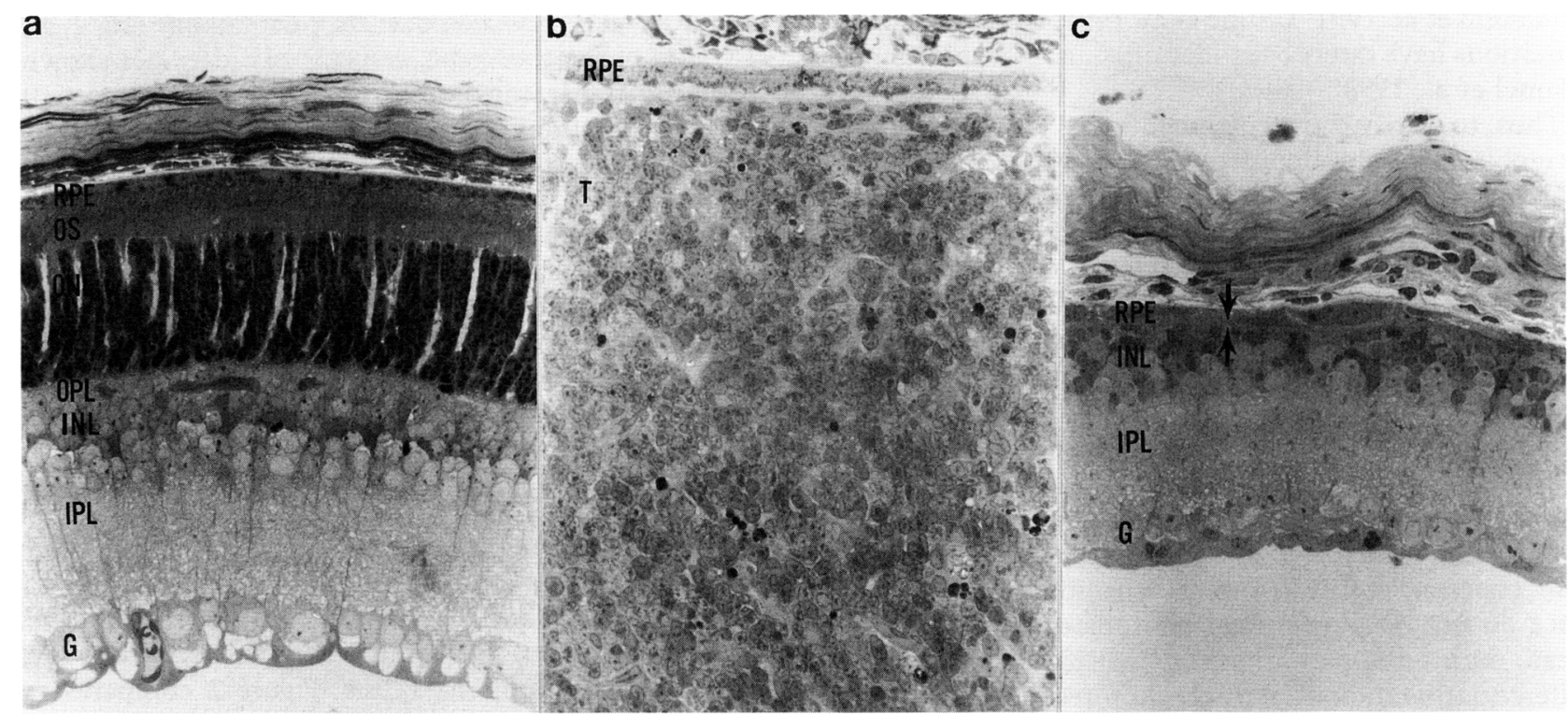

Figure 2. Histological comparison of retinas collected from a normal mouse, an IRBP-Tag mouse, and an IRBP-E7 mouse. (a) Retina from a 4-week-old normal mouse, X396 (b) Retina from a 2-week-old IRBP-Tag (IT-2) transgenic mouse in which a tumor mass (T) has replaced the photoreceptor cell layer. The IPL and ganglion cell layers are normal but not shown in this micrograph (magnification, $253 \times$ ). (c) Retina from a 4-week-old IRBP-E7-1 mouse, showing loss of the OS, the ONL, and the OPL (opposed arrows). Pyknotic cells are apparent within the outer region of the INL (magnification, $253 \times$ ). (RPE) Retinal pigmented epithelium-pigmented cell layer; (OS) outer segment-a differentiated feature of photoreceptor cells comprised of stacks of rhodopsin laden membranous disks; (ONL) outer nuclear layer-contains the photoreceptor cell nuclei; (OPL) outer plexiform layer-comprised of photoreceptor cell axons and synapses with dendrites from the horizontal and bipolar cells; (INL) inner nuclear layer-comprised of bipolar, amacrine, and horizontal cells. (IPL) inner plexiform layer-comprised of axons from amacrine and bipolar cells and synapses with dendrites of ganglion cells; (G) ganglion cell layer-contains nuclei and cell bodies of ganglion cells.

in the number of dying cells between transgenic and normal retinas (Fig. 3e,f).

During normal murine retinal development, the outer plexiform (synaptic) layer (OPL) develops at P6 and clearly delineates the photoreceptor cell bodies of the outer nuclear layer (ONL) from the inner nuclear layer (INL) containing the cell bodies of the bipolar, horizontal, and amacrine cells. The OPL is comprised of rod and cone axonal projections and their synaptic junctions with dendrites of cells of the INL. However, the OPL is absent in retinas examined from IRBP-E7-1 animals on day P6 and fails to develop even at later stages. By P10 in IRBP-E7-1 mice, the inner and outer nuclear layers still comprise a single layer in which cellular numbers are markedly decreased and numerous dead or dying cells are evident (Fig. $3 \mathrm{~g}, \mathrm{~h}$ ). The overall thickness of the retina is $\sim 20 \%$ less than normal. By 4 weeks of age the entire photoreceptor cell layer is often absent and the thinned INL directly abuts the RPE (Fig. 2c).

In addition, the lenses of these mice appear abnormal relative to those of nontransgenic littermates (data not shown). We are currently investigating the significance of this observation.

\section{Apoptosis of photoreceptor cells in IRBP-E7-1 mice}

The elimination of photoreceptor cells within these mice led us to examine the mode of cell death within this layer, and specifically, to determine whether the dying cells possessed the molecular and ultrastructural features apoptosis. Retinas from mice at P4 were selected because this stage showed the maximum numbers of dying cells. The DNA of apoptotic cells is cleaved into large fragments corresponding in size to chromatin loops that often undergo further internucleosomal cleavage, resulting in DNA fragment sizes corresponding to multimers of $\sim 180$ bp (Wyllie 1992). Two methods have been developed to assay this DNA degradation. The terminal deoxyribonucleotidyl transferase (TdT) assay of Gavrieli et al. (1992) can be employed to label fragmented DNA using biotin-labeled dUTP and a streptavidin peroxidase assay on tissue sections embedded in paraffin. Our results show that relative to normal littermates, the P4 IRBP-E7-1 retinas exhibit excessive labeling of cells within the ventricular layer (Fig. 4a,b), indicating the presence of cells containing degraded DNA. Secondly, to determine whether internucleosomal cleavage could be detected, DNA was extracted from IRBPE7-1 P4 retinas and subjected to agarose gel electrophoresis. Nucleosome ladders were easily visualized in IRBP-E7-1 retinal DNA while no ladders were detected in retinal DNA from normal littermates (Fig. 5).

Ultrastructural analysis revealed nuclear condensation, reduced cytoplasmic volume, and intact morphology of other cellular organelles within dying cells in the ventricular layer (Fig. 6a-d). These features are morpho- 
Apoptosis or retinoblastoma in transgenic mice
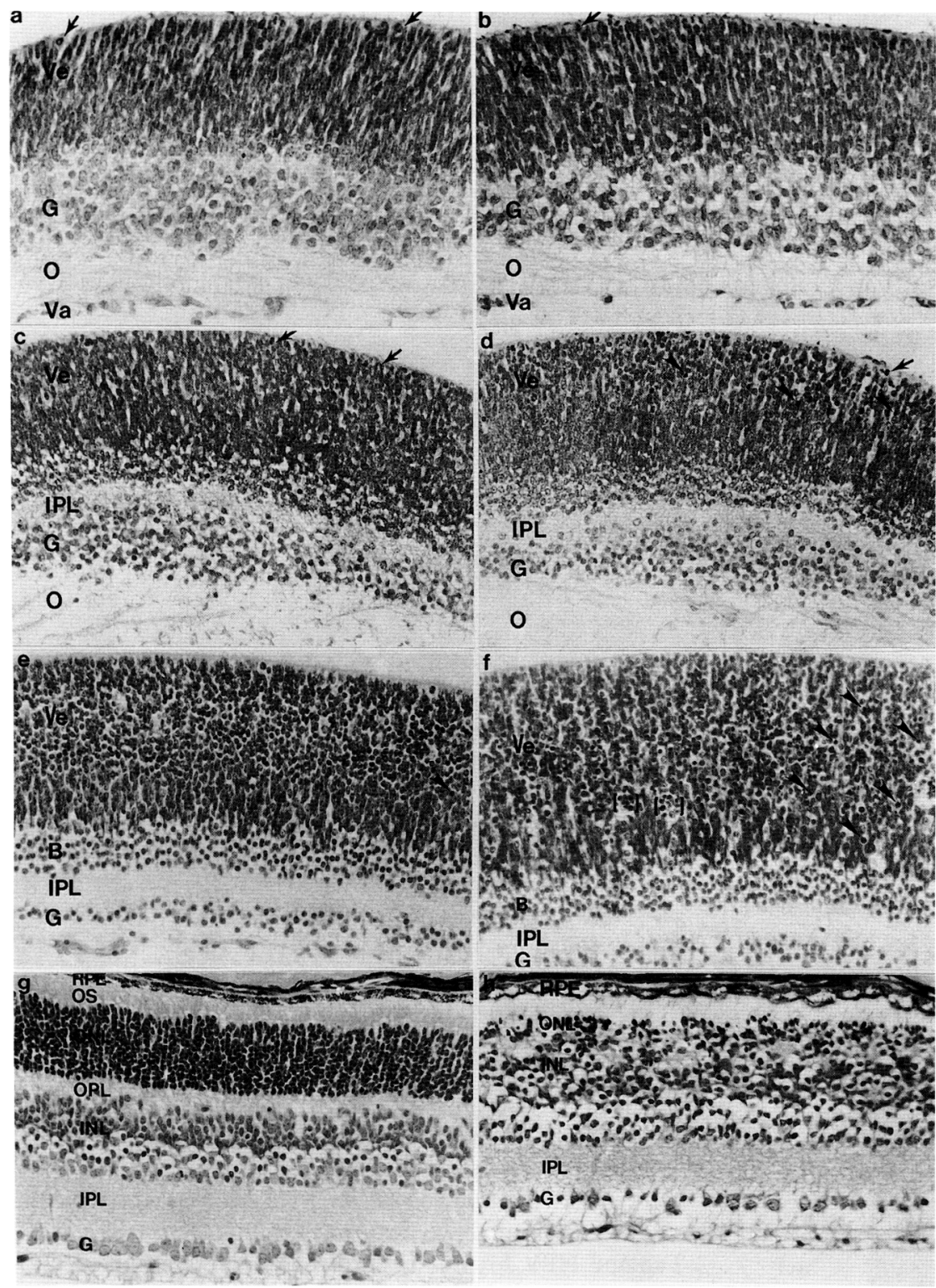
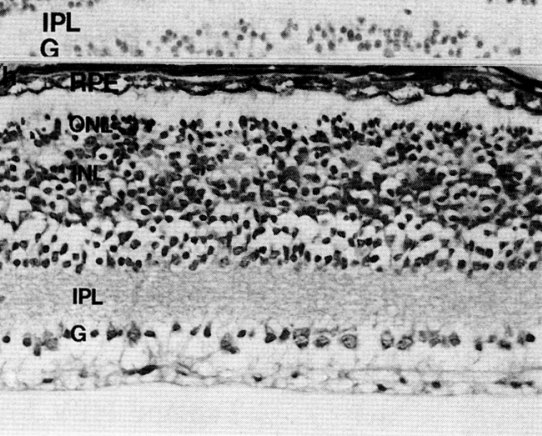

Figure 3. Developmental time course of IRBP-E7 retinal degeneration. E16 normal (a) and IRBP-E7-1 (b) retinas. Immature photoreceptor cells are interspersed with cells of the INL forming the ventricular stratum (Ve) at this early developmental stage. Arrows show mitotic nuclei along the outer boundary of the Ve. No obvious differences appear between normal and transgenic mice at this stage [hemotoxylin and eosin (H\&E); magnification 154X]. Postnatal day 1 normal (c) and IRBP-E7-1 (d) retinas. Dying cells are slightly more numerous within the Ve layer of transgenic mice (arrowheads). Mitotic activity is still evident at this stage in normal mice (arrows) (H\&E; magnification, 123 $\times$ ). P4 normal $(e)$ and IRBP-E7-1 (f) retinas. The Ve of the transgenic mouse appears less organized and contains numerous pyknotic nuclei occurring singly (arrowheads) and in clusters (brackets) (H\&E; magnification, $123 \times)$. P10 normal $(g)$ and IRBP-E7-1 $(h)$ retinas. The transgenic retina develops neither the OS nor the OPL, normally formed by differentiated photoreceptor cells. Dying cells are apparent within the remnants of the ONL (H\&E, magnification, $123 \times)$, (O) Optic nerve fiber layer; (Va) vascular tissue. (For other abbreviations, see legend to Fig. 1). logical hallmarks of apoptosis (Kerr et al. 1972; Wyllie et al. 1980; Schwartzman and Cidlowski 1993). In some cases, it was also possible to see neighboring cells engulfing membrane-bound apoptotic bodies (Fig 6e). Thus, histochemical, biochemical, and ultrastructural criteria of apoptosis in dying photoreceptor precursors in IRBPE7-1 mice were satisfied.

\section{IRBP-E7 mRNA expression}

The expression of both the endogenous IRBP gene and the IRBP-E7 transgene correlates with the presence of photoreceptor precursor cells within the developing retina (Fig. 7). The reverse transcription polymerase chain reaction (RT-PCR) was employed to detect endogenous IRBP and IRBP-E7 mRNA from IRBP-E7-1 retinas at var- ious stages. At P6, a stage at which photoreceptor precursor cells are still present in the IRBP-E7-1 retinas, both IRBP and E7 expression are detectable. Expression of both RNAs, however, is reduced in retinal RNA collected from 3.5-week-old transgenic mice, correlating with the dramatic reduction of photoreceptor cells shown by histological analysis of IRBP-E7-1 retinas compared with those of normal mice. IRBP and E7 expression is usually almost undetectable in retinas from adult IRBP-E7-1 mice (>6 months of age). However, the E7 signal is still significant in a small number of adult animals. This may be attributable to the presence of small focal tumors arising in other layers of the retina, as such tumors have been observed histologically in a small number of IRBP-E7-1 mice (not shown). We are currently investigating the origin and significance of these tumors. 

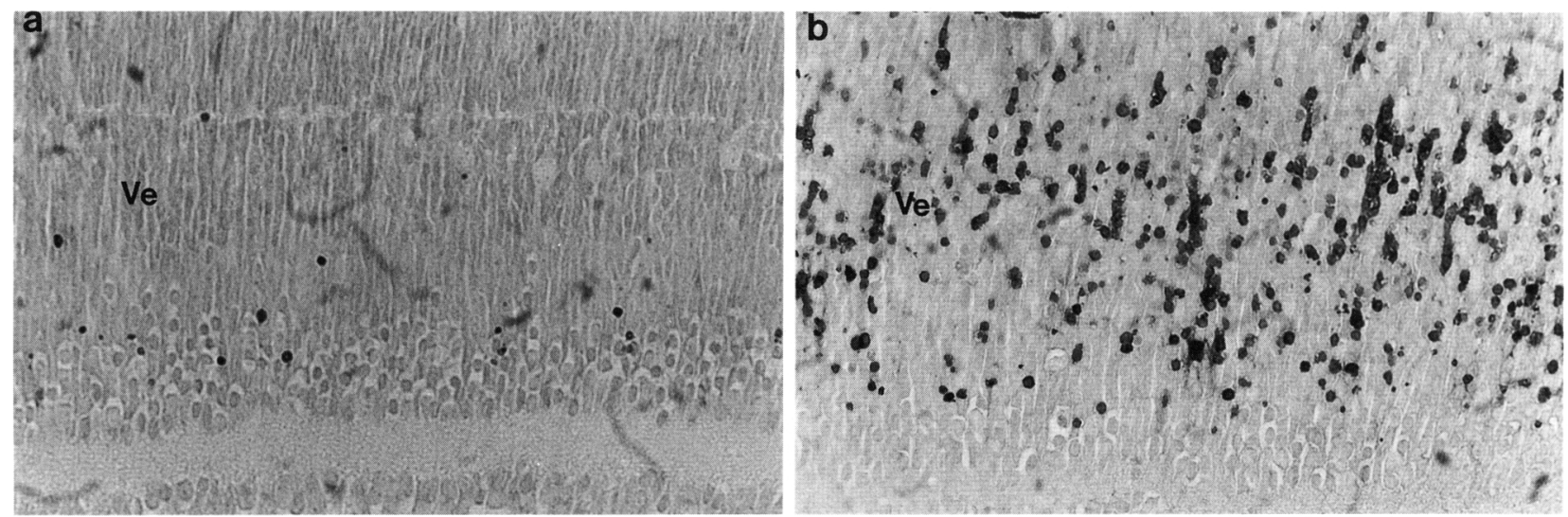

Figure 4. TdT assay on P4 normal and IRBP-E7 retinas. (a) The control retina shows the normal level of cellular death within the ventricular stratum (Ve) at this developmental stage. (b) An IRBP-E7-1 littermate exhibits elevated DNA fragmentation and cell death in the Ve. Sections were labeled by the procedure of Gavrieli et al. (1992).

\section{Inhibition of apoptosis in IRBP-E7-1 mice by the inactivation of $p 53$}

To determine whether the induction of apoptosis within this transgenic line was mediated by $\mathrm{p} 53$, we generated mice expressing the IRBP-E7 transgene in a p53 nullizygous background (Donehower et al. 1992). Through two rounds of crossings to p53 nullizygous mice, we generated mice that contained the IRBP-E7 transgene in a

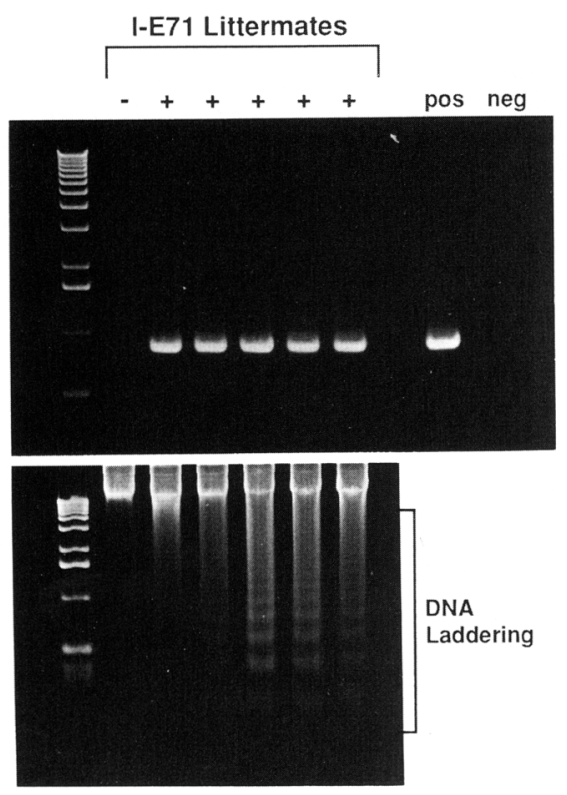

Figure 5. Retinal DNA collected from IRBP-E7 mice shows nucleosomal ladders. Normal $|-|$ and IRBP-E7-1 $|+|$ littermates are identified by PCR analysis of tail DNA using transgene-specific primers, which yield an 820 -bp product. Corresponding retinal DNA from each littermate was run on a $2 \%$ agarose gel. Bands corresponding to multiples of the nucleosome fragments $\mid \sim 180 \mathrm{bp})$ are observed only in the IRBP-E7 $\mid+1$ littermates. p53-deficient background. According to the segregation pattern of the IRBP-E7 transgene and mutant p53 alleles, littermates characteristically exhibited normal, degenerative, or retinoblastoma phenotypes. Southern and representative histological analyses from one such litter (Fig. 8a,b) show that the retinas from mice 11, 12, 15, 17 (E7 $-/ \mathrm{p} 53+-$ ), and 13 (E7 $-/ \mathrm{p} 53--$ ) are normal, retinas from mouse $16(\mathrm{E} 7+/ \mathrm{P} 53+-)$ underwent retinal degeneration (like the $\mathrm{E} 7+/ \mathrm{p} 53++$ mice), and retinas from mouse $14(E 7+/ \mathrm{p} 53--)$ exhibited bilateral tumors of photoreceptor cell origin (similar to those seen in IRBP-Tag mice).

\section{Discussion}

We have produced a transgenic mouse model in which we could investigate the specific genetic lesions sufficient for the induction of retinoblastoma or apoptosis. The expression of two different viral oncoproteins, SV40 Tag and HPV E7, has been directed specifically to photoreceptor cells by use of the IRBP promoter. IRBP-Tag transgenic mice exhibit tumors with the histological and ultrastructural features of an undifferentiated and fairly aggressive form of human retinoblastoma (Al-Ubaidi et al. 1992; Howes et al. 1994). However, because Tag binds to and inactivates p53 as well as pRb, it remained unclear whether $\mathrm{p} 53$ was involved in mediating tumorigenesis in this model.

Recently, several groups have developed mice nullizygous for the $R B$ gene $(R B-/-)$ (Clarke et al. 1992; Jacks et al. 1992; Lee et al. 1992). These mice are nonviable past embryonic day 16 , because of developmental abnormalities of the hematopoietic and nervous systems. Although the retinal layers appear normal upon histological examination at E16, this model does not permit examination of the development of retinoblastoma, as mitosis continues within the normal mouse retina until well after birth, beyond the stage of nonviability for the $R B-/$ - mouse. However, mice hemizygous for the $R B$ gene $(R B+/-)$ are viable and exhibit normal retinal de- 


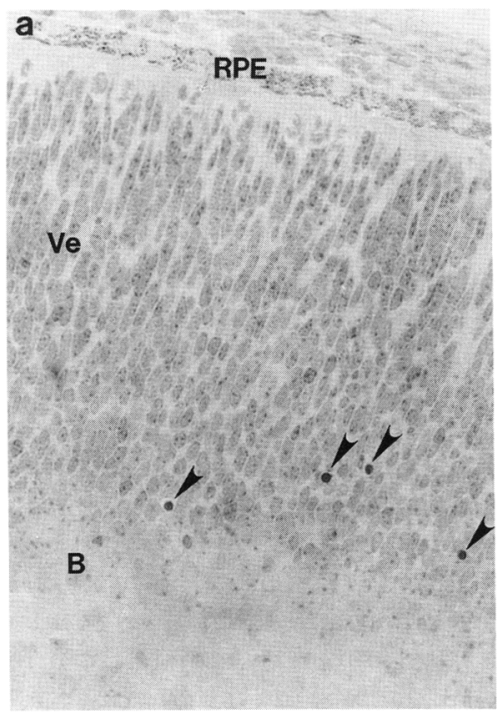

b
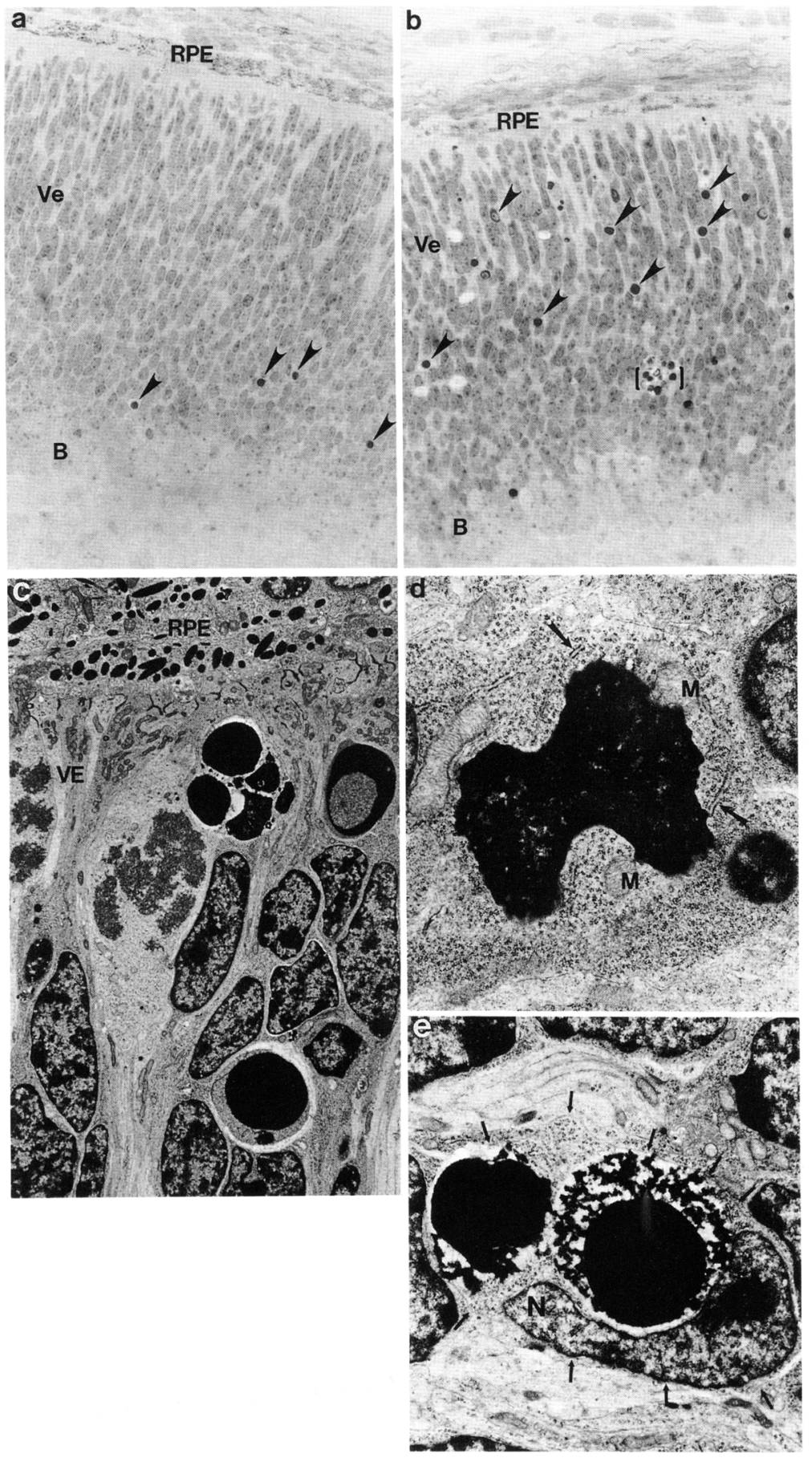

Figure 6. P4 Retinas from normal and IRBP-E7 littermates show ultrastructural features of apoptosis. (a) Normal retina (magnification, $315 \times$ ). (b) IRBPE7-1 retina (magnification, $315 \times$ ). Note individual (arrows) and clustered (brackets) apoptotic cells. $(c)$ Higher magnification of IRBP-E7-1 retina containing apoptotic cells showing nuclear condensation and scanty cytoplasm (magnification, $2226 \times$ ). (B) Bipolar cells. (d) An apoptotic cell shows nuclear condensation and intact organelles, including mitochondrion $(\mathrm{M})$, and rough endoplasmic reticulum (arrows) (magnification, 10,7100 $\times$ ). (e) An apoptotic cell phagocytosed by neighboring normal cell. The plasma membrane of the phagocytosing cell is indicated by arrows. (N) nucleus of normal cell (magnification, $4830 \times$ ). (For other abbreviations, see legend to Fig. 1). velopment. It is interesting that these mice fail to develop retinoblastoma, because $-90 \%$ of children who inherit one mutant $R B$ allele develop bilateral retinoblastoma. This difference suggests that mouse models may not parallel human retinoblastoma accurately in all regards. Naturally occurring retinoblastomas in mice have not been reported (Hogan and Albert 1991). Although this may be attributable to a fundamental difference in the regulation of cellular proliferation and differ- entiation in the mouse retina compared with the human, alternatively it may simply reflect the greatly reduced probability of acquiring an additional spontaneous $R B$ "hit" in mice, whose retinas contain fewer target cells and a significantly narrowed temporal window of sensitivity to $R B$ inactivation as a consequence of their shorter period of retinal development.

An alternative approach is to introduce a transgene that results in inactivation of $\mathrm{pRb}$ within photoreceptor 


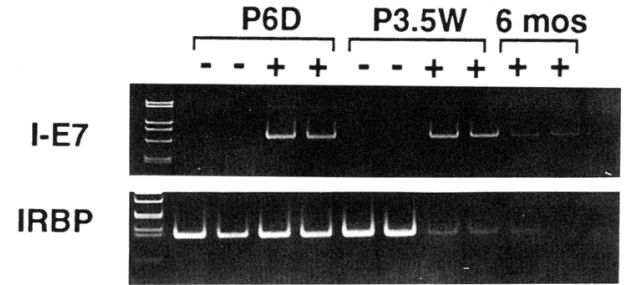

Figure 7. IRBP-E7 transgene and endogenous IRBP expression. Total RNA was extracted from normal and IRBP-E7-1 retinas collected at postnatal day $6(\mathrm{P} 6 \mathrm{D}), 3.5$ weeks $(\mathrm{P} 3.5 \mathrm{~W})$, and 6 months of age. RT-PCR using primers from the endogenous IRBP gene and the IRBP-E7 transgene yield amplification products of 131 and $308 \mathrm{bp}$, respectively. Primer sequences were selected to flank introns so that contaminating DNA would yield larger amplification products.

cells prior to their terminal differentiation. For this purpose, we introduced an IRBP-E7 transgene into mice to functionally inactivate photoreceptor $\mathrm{pRb}$ while leaving p53 activity intact. The IRBP promoter was selected for these studies because it has been shown to be transcriptionally active prior to the terminal differentiation of photoreceptor cells. Transgenic mice containing an IRBP-chloramphenicol acetyltransferase (CAT) transgene show CAT activity in the retina as early as E13 (Al-Ubaidi et al. 1992). In addition, the IRBP protein has been shown by immunohistochemistry to be produced in murine retinoblasts by El6 (Carter-Dawson et al. 1986). The mitotic activity of rods peaks on the day of birth and terminates by P5 (Young 1985; Wang et al. 1992). Thus, the IRBP promoter should direct oncogene expression to photoreceptor cells prior to their terminal differentiation. Our results indicate that $\mathrm{pRb}$ inactivation by $\mathrm{E} 7$ binding is not sufficient for photoreceptor cell transformation, as the mice expressing IRBP-E7 do not develop retinoblastoma of photoreceptor cell origin.

Rather than inducing transformation of photoreceptor cells, expression of E7 results in apoptotic degeneration of the photoreceptor layer. A number of murine retinal degeneration syndromes (rd, rds, rhodopsin mutants) exhibit apoptotic photoreceptor cell death (Chang et al. 1993; Lolley et al. 1994; Papermaster and Neer 1994; Portera-Cailliau et al. 1994). In addition, apoptosis occurs normally during retinal development, and this process has been well characterized in the murine retina (Young 1984). Apoptotic cells in the IRBP-E7-1 mice, while present in greatly increased numbers, show the same morphological features as the apoptotic cells of a normal developing retina. Cells undergoing apoptosis exhibit nuclear and cytoplasmic condensation and fragmentation. Unlike necrotic cells that undergo lysis, the degeneration of apoptotic cells involves an orderly separation of intact cellular components into membranebound bodies that are phagocytosed by neighboring cells or, in some tissues, by macrophages. Nucleosome ladders could be detected from IRBP-E7-1 mice but not control littermates, demonstrating that the levels of apoptotic cell death are greatly elevated in the retinas of mice expressing the transgene. Histological and ultrastructural examination of retinas from IRBP-E7-1 mice revealed that cell death specifically involved the photoreceptor cells or their ventricular layer precursors.

It has been proposed that p53 may prevent transformation by regulating the cellular decision to undergo programmed cell death in response to environmental or genetic perturbations (Yonish-Rouach et al. 1993). Recent studies have shown that tumor cells that have undergone p53 mutations resulting in loss of the protein undergo apoptosis when transfected with wild-type p53 (Shaw et al. 1992; Yonish-Rouach et al. 1993).

A similar model for the molecular induction of apoptosis has been proposed from the study of the transforming viruses that specifically inactivate p53 to inhibit the suicide response to oncogenic challenge (Lowe et al. 1993b). The adenovirus E1A protein, which binds to and functionally inactivates $\mathrm{pRb}$, induces apoptosis of primary rodent cells when expressed in the presence of wild-type p53 (Debbas and White 1993). In contrast, a temperature-sensitive mutant form of $\mathrm{p} 53$ was shown to cooperate with ElA to transform primary cells at the higher temperature while inducing apoptosis at the lower, permissive temperature. Furthermore, the $55 \mathrm{~K}$ E1B protein, which contains p53-binding activity, blocked the p53-induced apoptotic response to E1A. Finally, embryonic fibroblasts and immature thymocytes from normal mice, when transfected with the E1A oncoprotein, undergo apoptosis in response to chemotherapeutic drugs and radiation treatment. This response is mediated by $\mathrm{p} 53$, because it was not observed in cells from p53 nullizygous mice (Lowe et al. 1993a,b).

Like the E1A viral protein, the E7 proteins of HPV-16 and HPV- 18 have been shown to induce cell death in the presence of wild-type p53 activity. Human cultured keratinocytes transfected with HPV-16 E7 alone were nonviable (Hudson et al. 1990), and antisense oligonucleotides for HPV E6 (which accelerates the degradation of p53) (Scheffner et al. 1990), but not E7, resulted in cell death in oral and cervical cancer cell lines that contain HPV-18 (Steele et al. 1993). Thus, the death of photoreceptors in the IRBP-E7/p53 + mice indicates the diverse cell types responsive to this combination of genetic actions.

It is intriguing that the peak of cell death in the IRBPE7 retinas occurs at precisely the developmental time point when the majority of photoreceptor cells are normally undergoing terminal differentiation. A number of recent experiments demonstrate that $\mathrm{pRb}$ accumulates in cells prior to their differentiation (Endo and Goto 1992; Goodrich and Lee 1993; Slack et al. 1993), suggesting a model in which $\mathrm{pRb}$ is a key regulator of cell cycle control in cells that are undergoing differentiation. Because HPV-16 E7 binds and functionally inactivates $\mathrm{pRb}$, its expression in photoreceptor cells may prevent $\mathrm{pRb}$ induction of their differentiation within IRBP-E7 mice, rendering them susceptible to the action of a p53-dependent apoptotic pathway.

The apoptotic cell death of photoreceptor precursor cells in IRBP-E7 mice is consistent with this model. Be- 
a

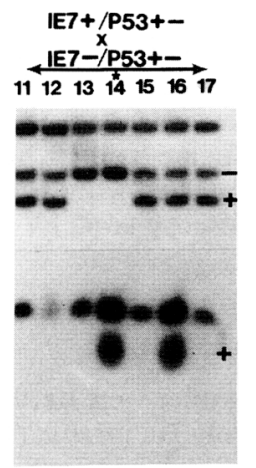

Figure 8. Results of crossing IRBP-E7-1 and p53 nullizygous mice. (a) Southern analysis of offspring from a mating of IRBP-E7+1 $\mathrm{p} 53+-$ and IRBP-E7 - /p53 + - mice. The $6.5-\mathrm{kb}$ band $(-)$ originates from the disrupted $\mathrm{p} 53$ allele; the $5-\mathrm{kb}$ band $|+|$ corresponds to the normal p53 allele. The IRBP-E7 transgene was used to probe tail DNA from the same littermates. The upper band corresponds to the endogenous $5^{\prime}$-flanking region of the IRBP gene present in all samples; the lower band $(+)$ indicates the presence of the transgene. (b) Retinal histology from 4-week-old mice 13, 16, and 14 demonstrates the exact correlation of the phenotype with the presence or absence of E7 and p53. Retinas expressing E7+/p53+ are apoptotic; those expressing E7 + in p53 nullizygous mice develop a poorly differentiated tumor of photoreceptor precursor cells (magnification, $245 \times 1$.

cause E7 binds other cell cycle regulatory proteins in addition to $\mathrm{pRb}$, including $\mathrm{p} 107$ and $\mathrm{E} 2 \mathrm{~F}-\mathrm{cyclin} \mathrm{A}-\mathrm{cdk} 2$ complex (Dyson et al. 1992; Arroyo et al. 1993), the involvement of these proteins cannot be excluded in this mouse model and are currently being investigated. However, the observation of massive neuronal cell death in the $R B$ nullizygous mice (Clarke et al. 1992; Jacks et al. 1992; Lee et al. 1992) suggests that loss of $\mathrm{pRb}$ function in the presence of an intact p53 gene creates a sufficient disruption of the cell cycle to trigger cell death in at least a subpopulation of neurons.

Regardless of the mechanism by which $\mathrm{E} 7$ perturbs the cell cycle, the results from our studies clearly demonstrate that the induction of apoptosis in the IRBP-E7 mice is p53 dependent, as mice expressing E7 in a p53 nullizygous background fail to exhibit apoptosis but, rather, form retinoblastomas. Interestingly, in this transgenic mouse model, retinal fate is determined by the segregation pattern of the E7 transgene and functional
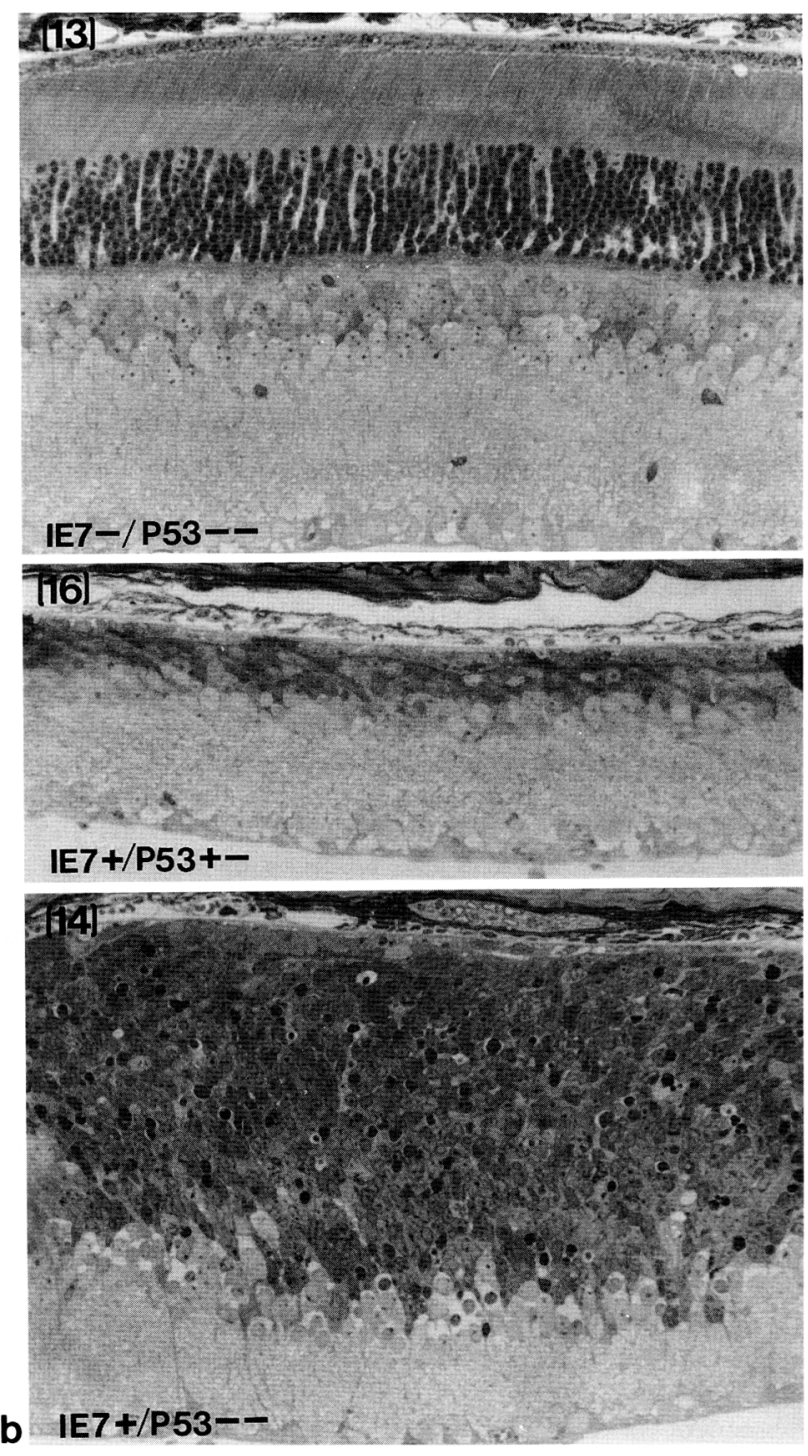

p53 alleles. The IRBP-Tag and IRBP-E7 transgenic mouse models therefore provide useful in vivo systems for further examining the molecular basis of the cellular decision to undergo differentiation, apoptosis, or transformation.

\section{Materials and methods}

\section{IRBP-E7 transgene construction}

A 317-bp EcoRI-HindIII fragment containing the start codon, coding sequence, and stop codon for HPV-16 E7 was excised from the pGem-E7 plasmid (generously provided by William Phelps, Burroughs Wellcome Co., Research Triangle Park, NCl, and the ends were filled in with Klenow DNA polymerase. The plasmid, pBS/pKCR3 $\triangle$ RI, a modification of pKCR (Matsui et al. 1990), containing part of exon 2, the second intron, and exon 3 , including the polyadenylation site, of the rabbit $\beta$-globin gene, was linearized with EcoRI, which cuts once within exon 3, and then blunt-ended with Klenow DNA polymerase. The E7 frag- 
ment was then subcloned into the linearized pBS/pKCR3 $3 \mathrm{RI}$ vector. A $1.9-\mathrm{kb}$ BamHI fragment containing the IRBP promoter Igenerously provided by Diane Borst, National Eye Institute, Bethesda, MD, and John Nickerson, Emory University, Atlanta, GA) was ligated into the BamHI site within the polycloning region located $5^{\prime}$ to exon 2 of the rabbit $\beta$-globin sequence in $\mathrm{pBS} / \mathrm{pKCR} 3-\mathrm{E} 7$. Plasmids containing both the promoter and E7 fragments in the correct orientation were verified by restriction mapping. The 3.4-kb ClaI-XhoI fragment containing the IRBPE7 transgene was excised and purified for injection using Geneclean (Bio 101, La Jolla, CA).

\section{Production and identification of transgenic mice}

The IRBP-E7 fragment at a concentration of $2 \mu \mathrm{g} / \mathrm{ml}$ was microinjected into the male pronucleus of fertilized one-cell mouse embryos essentially as described (Hogan et al. 1986). The $\mathrm{F}_{2}$ embryos were obtained from matings of $\mathrm{CB} \mathrm{F}_{1} \mid \mathrm{C} 57 \mathrm{Bl} /$ $6 \times \mathrm{BALB} / \mathrm{c}$ ) males and females (Harlan Sprague-Dawley, Inc.). The injected embryos were reimplanted into pseudopregnant B6D2 female mice (Harlan Sprague-Dawley, Inc.). Transgenic founder mice were identified by Southern blot analysis of tail DNA obtained at the time of weaning. Transgenic mice from subsequent generations were identified by slot blot analysis using the IRBP-E7 transgene as a probe, or by PCR using a $5^{\prime}$ primer derived from the IRBP region $15^{\prime}$-GCAGGACCACAGCCTTGTACACACG-3') and a $3^{\prime}$ primer derived from E7 sequences (5'-TGGGCTCTGTCCGGTTCTGCTTGTC- 3 '). The PCR program included 35 cycles of $95^{\circ} \mathrm{C}$ for $1 \mathrm{~min}, 60^{\circ} \mathrm{C}$ for $1 \mathrm{~min}$, and $72^{\circ} \mathrm{C}$ for $1 \mathrm{~min}$, or $2 \mathrm{~min}$ for the last cycle. Southern and slot blot analysis were performed with Nytran filters (Schleicher \& Schuell), and probes were generated by random oligonucleotide labeling (Pharmacia Biochemicals, Inc.), using $\left[\alpha^{-32}\right.$ P $]$ dCTP (DuPont-NEN).

\section{Identification of p53 heterozygous and nullizygous mice}

p53 nullizygous mice (TSG-p53), obtained from GenPharm, were bred to IRBP-E7-1 mice to generate $F_{1}$ offspring that contain the IRBP-E7 transgene in a p53 heterozygous background. Subsequent backcrosses to p53 nullizygous mice resulted in the generation of offspring with or without the transgene and one or two copies of the mutant p53 allele. Mice heterozygous or nullizygous for the wild-type p53 gene were identified by PCR and Southern blot analysis of tail DNA. A sense $5^{\prime}$ primer specific for a region within the murine p53 exon 4 (5'-GGGACAGCCAAGTCTGTTATGTGC-3') and two antisense $3^{\prime}$ primers, specific for either exon 6 of the normal p53 allele $\left(5^{\prime}\right.$ CTGTCTTCCAGATACTCGGGATAC-3') or the neo cassette (5'-TTTACGGAGCCCTGGCGCTCGATGT-3'), were used for PCR analysis. The PCR program for this reaction included 35 cycles of $94^{\circ} \mathrm{C}$ for $1 \mathrm{~min}, 62^{\circ} \mathrm{C}$ for $1 \mathrm{~min}, 72^{\circ} \mathrm{C}$ for $2 \mathrm{~min}$, with an autoextend command of an additional $10 \mathrm{sec}$ for each subsequent cycle extension time $\left(\right.$ at $72^{\circ} \mathrm{C}$ ). For Southern analysis, 15 $\mu \mathrm{g}$ of tail DNA was digested with BamHI, electrophoresed, and blotted onto Nytran filters. A 605-bp oligolabeled KpnI fragment of the plasmid LR10 (GenPharm) was used to identify the mutant $6.5-\mathrm{kb}$ and normal $5.0-\mathrm{kb}$ p53 alleles.

\section{Histological examination of retinas from various developmental stages}

For the data in Figure 3, the eyes from mice ranging in age from E16 to P10 were fixed in $10 \%$ neutral formalin (phosphate buffered) (Fisher) and embedded in paraffin for light microscopy.

\section{Ultrastructural examination of retinas}

For the data in Figures 2, 5, and 8, eyes were removed, opened by incising the cornea to remove the lens, fixed in $1 \%$ glutaraldehyde (Ladd) and phosphate-buffered $4 \%$ paraformaldehyde (Tousimis), and then embedded in epon. Sections ( $1 \mu \mathrm{m}$ thick) were stained with toludine blue for light microscopy, and ultrathin sections were stained with uranyl acetate and lead citrate for electron microscopy at $60 \mathrm{kV}$ on a Philips 301 microscope.

\section{End-labeling of fragmented DNA}

Eyes removed from $\mathrm{P} 4$ mice were fixed in $10 \%$ buffered formalin and embedded in Poly-Fin paraffin (Triangle Biomedical Sciences). Sections ( $4 \mu \mathrm{m}$ thick) were cut, dewaxed, and permeabilized with proteinase K (Sigma). DNA was end-labeled with biotinylated-dUTP (Boehringer Mannheim) using deoxyribonucleotidyl transferase (GIBCO BRL), according to the procedure of Gavrieli et al. (1992), as modified by Tim McDonnell (pers. comm.). The bound biotin was detected using a streptavidinhorseradish peroxidase (HRP) conjugate (DAKO) and visualized with a DAB chromagen (Sigma).

\section{Analysis of DNA ladders}

Mice at $\mathrm{P} 4$ were sacrificed, the retinas were removed, and DNA was extracted (Hogan et al. 1986). Two micrograms of each DNA sample was electrophoresed on a $2 \%$ agarose gel, stained with ethidium bromide, and photographed.

\section{Analysis of RNA}

Total RNA was extracted from retinal tissue according to the protocol of Chomczynski and Sacchi (1987). Transgene mRNA was detected by use of the Thermostable rTth Reverse Transcriptase RNA PCR kit (Perkin-Elmer Cetus). The $3^{\prime}$ primers from E7 (5'-TGGGCTCTGTCCGGTTCTGCTTGTC-3') and IRBP $\left(5^{\prime}\right.$-GAATCTCAAGTAGCCAATGT- $\left.3^{\prime}\right)$-coding regions were used in separate reactions for reverse transcription of 250 ng of retinal RNA for each sample. Addition of the 5' IRBP primer $\left(5^{\prime}\right.$-CAGAGGATGCCAAAGACCGA-3') and the $5^{\prime}$ IRBP primer (5'-CAGAGGATGCCAAAGACCGA-3') to the reaction mixture for PCR amplification of the IRBP-E7 and IRBP cDNAs yields amplicons of 866 and $131 \mathrm{bp}$ in length, respectively. The $3^{\prime}$ primer for IRBP-E7 was annealed at $53^{\circ} \mathrm{C}$ for 10 min, whereas the $3^{\prime}$ primer for IRBP was annealed at $60^{\circ} \mathrm{C}$ for 10 min. Extensions of both primers were carried out at $70^{\circ} \mathrm{C}$ for 2.5 min. The conditions of PCR amplification for IRBP-E7 reactions are as outlined above except that amplification was carried out for 26 cycles. The PCR amplification program for IRBP includes $94^{\circ} \mathrm{C}$ for $1 \mathrm{~min}, 55^{\circ} \mathrm{C}$ for $1 \mathrm{~min}$, and $72^{\circ} \mathrm{C}$ for $1 \mathrm{~min}$ for 26 cycles.

\section{Acknowledgments}

We gratefully acknowledge the excellent technical assistance of Barbara Koop, Shellye Lampkin, and Donna Clarkson. We also thank Drs. Diane Borst and John Nickerson for providing the murine IRBP promoter construct and Dr. William Phelps for providing the pGem-E7 plasmid. This research was supported in part by Cancer Center Support grant P30CA54174 from the National Cancer Institute, by National Institutes of Health (NIH) grant EYO9213 (to J.J.W.); by EYO6891 (to D.S.P.); by NIH grant EYO1917 and American Institute for Cancer Research grant 91A44 (to D.M.A.); and by NIH-Fogarty International Re- 
search Fellowship grant TWO4797, the Belgian American Educational Foundation, and the Vesalius Foundation, Brussels (to J.G.H.L.)

The publication costs of this article were defrayed in part by payment of page charges. This article must therefore be hereby marked "advertisement" in accordance with 18 USC section 1734 solely to indicate this fact.

\section{References}

Al-Ubaidi, M.R., R.L. Font, A.B. Quiambao, M.J. Keener, G.I. Liou, P.A. Overbeek, and W. Baehr. 1992. Bilateral retinal and brain tumors in transgenic mice expressing simian virus 40 large $T$ antigen under control of the human interphotoreceptor retinoid-binding protein promoter. J. Cell Biol. 119: 1681-1687.

Arroyo, M., S. Bagchi, and P. Raychaudhuri. 1993. Association of the human papillomavirus type $16 \mathrm{E} 7$ protein with the S-phase-specific E2F-cyclin A complex. Mol. Cell. Biol. 13: 6537-6546.

Bookstein, R., J.-Y. Shew, P.-L. Chen, P. Scully, and W.-H. Lee. 1990. Suppression of tumorigenicity of human prostate carcinoma cells by replacing a mutated RB gene. Science 247: 712-715.

Carter-Dawson, L., R.A. Alvarez, S.-L. Fong, G.I. Liou, H.G. Sperling, and C.D.B. Bridges. 1986. Rhodopsin, 11-cis vitamin $\mathrm{A}$, and interstitial retinol-binding protein (IRBP) during retinal development in normal and rd mutant mice. Dev. Biol. 116: 431-438.

Cavenee, W.K., M.F. Hansen, M. Nordenskjold, E. Kock, I. Maumenee, J.A. Squire, R.A. Phillips, and B.L. Gallie. 1985. Genetic origin of mutations predisposing to retinoblastoma. Science 228: 501-503.

Chang, G.Q., Y. Hao, and F. Wong. 1993. Apoptosis: Final common pathway of photoreceptor death in $\mathrm{rd}$, rds, and rhodopsin mutant mice. Neuron 11: 595-605.

Chomczynski, P. and N. Sacchi. 1987. Single-step method of RNA isolation by acid guanidinium thiocyanate-phenolchloroform extraction. Anal. Biochem. 162: 156-159.

Clarke, A.R., E.R. Maandag, M. van Roon, N.M.T. van der Lugt, M. van der Valk, M.L. Hooper, A. Berns, and H. te Riele. 1992. Requirement for a functional $\mathrm{Rb}-1$ gene in murine development. Nature 359: 328-330.

Debbas, M. and E. White. 1993. Wild-type p53 mediates apoptosis by E1A, which is inhibited by E1B. Genes \& Dev. 7: 546-554.

DeCaprio, J.A., J.W. Ludlow, J. Figge, J.-Y. Shew, C.-M. Huang, W.-H. Lee, E. Marsilio, E. Paucha, and D.M. Livingston. 1988. SV40 large tumor antigen forms a specific complex with the product of the retinoblastoma susceptibility gene. Cell 54: 275-283.

Donehower, L.A., M. Harvey, B.L. Slagle, M.J. McArthur, C.A.J. Montgomery, J.S. Butel, and A. Bradley. 1992. Mice deficient for p53 are developmentally normal but susceptible to spontaneous tumours. Nature 356: 215-221.

Dunn, J.M., R.A. Phillips, A.J. Becker, and B.L. Gallie. 1988. Identification of germline and somatic mutations affecting the retinoblastoma gene. Science 241: 1797-1800.

Dyson, N., P.M. Howley, K. Munger, and E. Harlow. 1989. The human papilloma virus-16 E7 oncoprotein is able to bind to the retinoblastoma gene product. Science 243: 934-937.

Dyson, N., P. Guida, K. Munger, and E. Harlow. 1992. Homologous sequences in adenovirus E1A and human papillomavirus E7 proteins mediate interaction with the same set of cellular proteins. J. Virol. 66: 6893-6902.
Endo, T. and S. Goto. 1992. Retinoblastoma gene product $\mathrm{Rb}$ accumulates during myogenic differentiation and is deinduced by the expression of SV40 large T antigen. J. Biochem. 112: $427-430$.

Friend, S.H., R. Bernards, S. Rogelj, R.A. Weinberg, J.M. Rapaport, D.M. Albert, and T.P. Dryja. 1986. A human DNA segment with properties of the gene that predisposes to retinoblastoma and osteosarcoma. Nature 323: 643-646.

Fung, Y.-K.T., A.L. Murphree, A. T'Ang, J. Qian, S.H. Hinrichs, and W.F. Benedict. 1987. Structural evidence for the authenticity of the human retinoblastoma gene. Science 236: 16571661.

Gavrieli, Y., Y. Sherman, S.A. Ben-Sasson. 1992. Identification of programmed cell death in situ via specific labeling of nuclear DNA fragmentation. J. Cell Biol. 119: 493-501.

Goodrich, D.W. and W.H. Lee. 1993. Molecular characterization of the retinoblastoma susceptibility gene. Biochim. Biophys. Acta 1155: 43-61.

Hamel, P.A., R.A. Phillips, M. Muncaster, and B.L. Gallie. 1993. Speculations on the roles of $R B 1$ in tissue-specific differentiation, tumor initiation, and tumor progression. FASEB $I$. 7: 846-854.

Hanahan, D. 1985. Heritable formation of pancreatic $\beta$-cell tumors in transgenic mice expressing recombinant insulin/ simian virus 40 oncogenes. Nature 315: 115-122.

Harbour, J.W., S.-L. Lai, J. Whang-Pang, A.F. Gazdar, J.D. Minna, and F.J. Kaye. 1988. Abnormalities in structure and expression of the human retinoblastoma gene in SCLC. Science 241: 353-357.

Hensel, C.H., C.L. Hsieh, A.F. Gazdar, B.E. Johnson, A.Y. Sakaguchi, and S.L. Naylor. 1990. Altered structure and expression of the human retinoblastoma susceptibility gene in small cell lung cancer. Cancer Res. 50: 3067-3072.

Hogan, R.N. and D.M. Albert. 1991. Does retinoblastoma occur in animals? Prog. Vet. Comp. Ophthalmol. 1: 72-83.

Hogan, B., F. Costantini, and E. Lacy. 1986. Manipulating the mouse embryo: A laboratory manual. Cold Spring Harbor Laboratory, Cold Spring Harbor, New York.

Hollstein, M., D. Sidransky, B. Vogelstein, and C.C. Harris. 1991. P53 mutations in human cancers. Science 253: 49-53.

Horowitz, J.M., D.W. Yandell, S.H. Park, S. Canning, P. Whyte, K. Buchkovich, E. Harlow, R.A. Weinberg, and T.P. Dryja. 1989. Point mutational inactivation of the retinoblastoma antioncogene. Science 243: 937-940.

Howes, K.A., J.G.H. Lasudry, D.M. Albert, and J.J. Windle. 1994. Photoreceptor cell tumors in transgenic mice. Invest. Ophthal. Vis. Sci. 35: 342-351.

Hudson, J.B., M.A. Bedell, D.J. McCance, and L.A. Laimins. 1990. Immortalization and altered differentiation of human keratinocytes in vitro by the E6 and E7 open reading frames of human papillomavirus Type 18. J. Virol. 64: 519-526.

Jacks, T., A. Fazeli, E.M. Schmitt, R.T. Bronson, M.A. Goodell, and R.A. Weinberg. 1992. Effects of an Rb mutation in the mouse. Nature 359: 295-300.

Kerr, J.F., A.H. Wyllie, and A.R. Currie. 1972. Apoptosis: A basic biological phenomenon with wide-ranging implications in tissue kinetics. Br. J. Cancer 26: 239-257.

Lane, D.P. and L.V. Crawford. 1979. T antigen is bound to a host protein in SV40-transformed cells. Nature 278: 261-263.

Lee, E.Y.-H.P., C.-Y. Chang, N. Hu, Y.-C.J. Wang, C.-C. Lai, K. Herrup, W.-H. Lee, and A. Bradley. 1992. Mice deficient for $\mathrm{Rb}$ are nonviable and show defects in neurogenesis and haematopoiesis. Nature 359: 288-294.

Lee, E.Y.-H.P., H. To, J.-Y. Shew, R. Bookstein, P. Scully, and W.-H. Lee. 1988. Inactivation of the retinoblastoma susceptibility gene in human breast cancers. Science 241: 218-221. 
Lee, W.-H., R. Bookstein, F. Hong, L.J. Young, J.Y. Shew, and E.Y.H. Lee. 1987. Human retinoblastoma susceptibility gene: Cloning, identification and sequence. Science 235: $1394-1399$.

Levine, A.J., J. Momand, and C.A. Finley. 1991. The p53 tumour suppressor gene. Nature 351: 453-456.

Linzer, D.I.H. and A.J. Levine. 1979. Characterization of a 54K dalton cellular SV40 tumor antigen present in SV40-transformed cells and uninfected embryonal carcinoma cells. Cell 17: 43-52.

Liou, G.I., L. Geng, M.R. Al-Ubaidi, S. Matragoon, G. Hanten, W. Baehr, and P.A. Overbeek. 1990. Tissue-specific expression in transgenic mice directed by the $5^{\prime}$-flanking sequences of the human gene encoding interphotoreceptor retinoid-binding protein. I. Biol. Chem. 265: 8373-8376.

Lolley, R.N., H. Rong, and C.M. Craft. 1994. Linkage of photoreceptor degeneration by apoptosis with inherited defect in phototransduction. Invest. Ophthal. Vis. Sci. 35: 358-362.

Lowe, S.W., H.E. Ruley, T. Jacks, and D.E. Housman. 1993a. p53-dependent apoptosis modulates the cytotoxicity of anticancer agents. Cell 74: 957-967.

Lowe, S.W., E.M. Schmitt, S.W. Smith, B.A. Osborne, and T. Jacks. 1993b. p53 is required for radiation-induced apoptosis in mouse thymocytes. Nature 362: 847-849.

Matsui, Y., S.A. Halter, J.T. Holt, B.L.M. Hogan, and R.J. Coffey. 1990. Development of mammary hyperplasia and neoplasia in MMTV-TGF $\alpha$ transgenic mice. Cell 61: 1147-1155.

Mellon, P.L., J.J. Windle, P. Goldsmith, C. Padula, J. Roberts, and R.I. Weiner. 1990. Immortalization of hypothalamic neurons by genetically targeted tumorigenesis. Neuron $5: 1-$ 10.

Mietz, J.A., T. Unger, J.M. Huibregtse, and P.M. Howley. 1992. The transcriptional transactivation function of wild-type p53 is inhibited by SV40 large T-antigen and by HPV-16 E6 oncoprotein. EMBO J. 11: 5013-5020.

Munger, K., B.A. Werness, N. Dyson, W.C. Phelps, E. Harlow, and P.M. Howley. 1989. Complex formation of human papillomavirus E7 proteins with the retinoblastoma tumor suppressor gene product. $E M B O$ /. 8: 4099-4105.

Nevins, J.R. 1992. The E2F transcription factor-A link between the $\mathrm{Rb}$ tumor suppressor protein and viral oncoproteins. Science 258: 424-429.

Oren, M. 1992. p53-The ultimate tumor suppressor gene. FASEB I. 6: 3169-3176.

Papermaster, D. and I. Neer. 1994. Apoptosis in inherited retinal degeneration. In Apoptosis (ed. E. Mihich and R.T. Schimke), pp. 15-30. Plenum, New York.

Portera-Cailliau, C., C.-H. Sung, J. Nathans, and R. Adler. 1994. Apoptotic photreceptor cell death in mouse models of retinitis pigmentosa. Proc. Natl. Acad. Sci. 91: 974-978.

Scheffner, M., B.A. Werness, J.M. Huibregtse, A.J. Levine, and P.M. Howley. 1990. The E6 oncoprotein encoded by human papillomavirus types 16 and 18 promotes the degradation of p53. Cell 63: 1129-1136.

Schwartzman, R.A. and J.A. Cidlowski. 1993. Apoptosis: The biochemistry and molecular biology of programmed cell death. Endocr. Rev. 14: 133-151.

Shaw, P., R. Bovey, S. Tardy, R. Sahli, B. Sordat, and J. Costa. 1992. Induction of apoptosis by wild-type p53 in a human colon tumor-derived cell line. Proc. Natl. Acad. Sci. 89: 4495-4499.

Slack, R.S., P.A. Hamel, T.S. Bladon, R.M. Gill, and M.W. McBurney. 1993. Regulated expression of the retinoblastoma gene in differentiating embryonal carcinoma cells. Oncogene 8: 1585-1591.

Steele, C., L.M. Cowsert, and E.J. Shillitoe. 1993. Effects of hu- man papillomavirus type 18-specific antisense oligonucleotides on the transformed phenotype of human carcinoma cell lines. Cancer Res. 53: 2330-2337.

Varley, J.M., J. Armour, J.E. Swallow, A.J. Jeffreys, B.A. Ponder, A. T'Ang, Y.K. Fung, W.J. Brammar, and R.A. Walker. 1989. The retinoblastoma gene is frequently altered leading to loss of expression in primary breast tumours. Oncogene 4: 725729.

Wang, M., V. Gaur, L.A. Donoso, and G.I. Liou. 1992. Timing of IRBP and opsin expression during photoreceptor development. ARVO Abstr. Invest. Ophthalmol. Vis. Sci. (Suppl.) 33: 694 .

Windle, J.J., D.M. Albert, J.M. O'Brien, D.M. Marcus, C.M. Disteche, R. Bernards, and P.L. Mellon. 1990. Retinoblastoma in transgenic mice. Nature 343: 665-669.

Windle, J.J., R.I. Weiner, and P.L. Mellon. 1990. Cell lines of the pituitary gonadotrope lineage derived by targeted oncogenesis in transgenic mice. Mol. Endocrinol. 4: 597-603.

Wyllie, A.H. 1992. The apoptosis endonuclease and its regulation. Sem. Immunol. 4: 389-397.

Wyllie, A.H., J.F. Kerr, and A.R. Currie. 1980. Cell death: The significance of apoptosis. Int. Rev. Cytol. 68: 251-306.

Yokoyama, T., G.I. Liou, R.B. Caldwell, and P.A. Overbeek. 1992. Photoreceptor-specific activity of the human interphotoreceptor retinoid-binding protein (IRBP) promoter in transgenic mice. Exp. Eye Res. 55: 225-233.

Yokota, Y., T. Akiyama, Y.K.T. Fung, W.F. Benedict, Y. Namba, M. Hanaoka, M. Wada, T. Terasaki, Y. Shimosato, T. Sugimura, and M. Terada. 1988. Altered expression of the retinoblastoma $(\mathrm{RB})$ gene in small-cell carcinoma of the lung. Oncogene 3: 471-475.

Yonish-Rouach, E., D. Grunwald, S. Wilder, A. Kimchi, E. May, J.-J. Lawrence, P. May, and M. Oren. 1993. p53-mediated cell death: Relationship to cell cycle control. Mol. Cell. Biol. 13: 1415-1423.

Young, R.W. 1984. Cell death during differentiation of the retina in the mouse. I. Comp. Neurol. 229: 362-373.

Young, R.W. 1985. Cell differentiation in the retina of the mouse. Anat. Rec. 212: 199-205. 


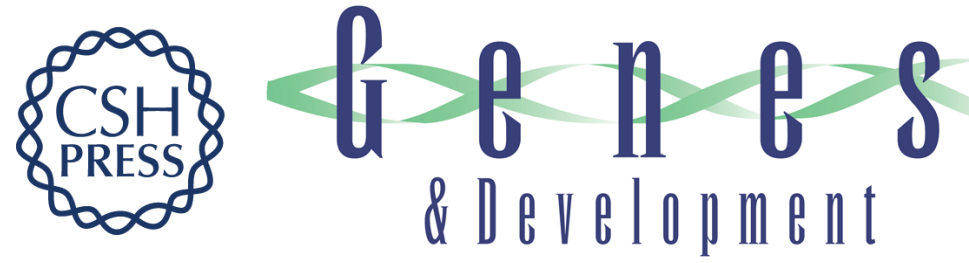

\section{Apoptosis or retinoblastoma: alternative fates of photoreceptors expressing the HPV-16 E7 gene in the presence or absence of p53.}

K A Howes, N Ransom, D S Papermaster, et al.

Genes Dev. 1994, 8:

Access the most recent version at doi:10.1101/gad.8.11.1300

References This article cites 63 articles, 25 of which can be accessed free at:

http://genesdev.cshlp.org/content/8/11/1300.full.html\#ref-list-1

License

Email Alerting

Service

Receive free email alerts when new articles cite this article - sign up in the box at the top right corner of the article or click here.

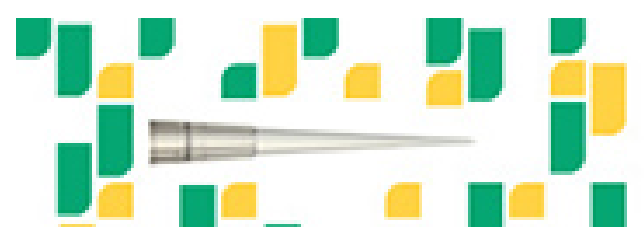

Focused on your science. 